\title{
Antimicrobial Activity of Chromolaena odorata Extracts against Bacterial Human Skin Infections
}

\author{
Srisuda Hanphakphoom ${ }^{1}$ Suchada Thophon ${ }^{1}$, Piyaporn Waranusantigul ${ }^{1}$, Niwat Kangwanrangsan ${ }^{2} \&$ \\ Sukhumaporn Krajangsang ${ }^{2}$ \\ ${ }^{1}$ Faculty of Science and Technology, Suan Dusit University, Bangkok, Thailand \\ ${ }^{2}$ Faculty of Science, Mahidol University, Phayathai Campus, Bangkok, Thailand \\ ${ }^{3}$ Faculty of Science, Srinakharinwirot University, Bangkok, Thailand \\ Correspondence: Srisuda Hanphakphoom, Faculty of Science and Technology, Suan Dusit University, Bangkok \\ 10700, Thailand. E-mail: srisuda_han@hotmail.com
}

Received: October 31, 2015

Accepted: November 27, 2015

Online Published: January 7, 2016

doi:10.5539/mas.v10n2p159

URL: http://dx.doi.org/10.5539/mas.v10n2p159

The research is financed by National Research Council of Thailand and Suandusit University.

\begin{abstract}
Leaf, stem and root of Chromolaena odorata were extracted by maceration extraction method using water, ethanol, methanol and hexane as solvents. The average percentage yield of leaf extracts in water $(12.16 \pm 0.13 \%)$, ethanol $(8.42 \pm 0.115 \%)$, methanol $(10.45 \pm 0.012 \%)$ and hexane $(2.37 \pm 0.215 \%)$ were significantly higher compared with stem and root extracts using the same solvents. All extracts were tested for antimicrobial activity against ten bacterial strains associated with human skin infections. Leaf extracts with ethanol, methanol and hexane solvents gave the best inhibitory activity against six gram-positive bacterial strains (Bacillus cereus TISTR 687, Enterococcus faecalis TISTR 379, Staphylococcus epidermidis TISTR 518, Staphylococcus aureus TISTR 1466, Streptococcus pyogenes ATCC 19615 and Propionibacterium acnes DMST 14916) and one gram-negative bacterial strain (Proteus vulgaris ATCC 13315). The hexane stem extract showed greater inhibitory activity against Pseudomonas aeruginosa ATCC 27853(15.3 $\pm 0.5 \mathrm{~mm})$, B. cereus TISTR 687(14.6 \pm 0.8 $\mathrm{mm})$ and Klebsiella pneumoniae TISTR $1843(14.0 \pm 1.0 \mathrm{~mm})$, while hexane root extract showed high inhibitory activity against Enterococcus faecalis TISTR $379(14.5 \pm 0.9 \mathrm{~mm})$ and Kleb. pneumoniae TISTR 1843 (14.7 \pm 0.6 $\mathrm{mm}$ ). The lowest minimum inhibitory concentration (MIC) of the ethanolic leaf extract was $0.81 \mathrm{mg} / \mathrm{mL}$ against Staph. aureus TISTR 1466, followed by methanolic and hexane leaf extracts with equal MIC of $1.62 \mathrm{mg} / \mathrm{mL}$ against both Staph. aureus TISTR 1466 and Strep. pyogenes ATCC 19615. The antimicrobial activity of the methanolic leaf extract of $C$. odorata was correlated with the amount of both total phenolic and flavonoid compounds. The results obtained suggest that the ethanolic, methanolic and hexane leaf extracts could be developed to treat bacterial skin infections. The hexane was sutiable solvent for extraction of the stem and root parts of C. odorata.
\end{abstract}

Keywords: Chromolaena odorata, bacterial human skin infection, antibacterial activity, MIC, MBC

\section{Introduction}

Bacterial skin infection strains commonly infect patients in hospitals, leading to high nosocomial infection rates and use of antimicrobial drugs. The nosocomial pathogens that exhibit the greatest antimicrobial resistance are Staph. aureus (52.2\%), E. coli (67.6\%), Acinetobacter baumannii (100\%) and Ps. aeruginosa (68.2\%) (Ahoyo et al., 2014). According to the U.S. Food and Drug Administration, the bacterial pathogens that most commonly cause acute bacterial skin and skin structure infections (ABSSSI) are Strep. pyogenes and Staph. aureus, including methicillin-resistant Staph. aureus; less common causes are Streptococcus spp., Entc. faecalis and gram-negative bacteria. Furthermore, a report by the World Health Organization (WHO) in 2014 found antibacterial resistance in E. coli, Kleb. pneumoniae, Staph. aureus, Strep. pneumoniae, nontyphoidal Salmonella (NTS), Shigella spp. and Neisseria gonorrhoeae.

Nowadays, hospital-acquired infections (HAIs) are a major cause of patient morbidity and mortality, and are correlated with fomites. Fomites are reservoirs of pathogens which can infect patients by direct contact or 
indirectly from touching contaminated hospital environmental surfaces (Mangicaro, 2012). At a teaching hospital in northern Nigeria, pathogenic bacteria were found on $65.7 \%$ of the samples tested (e.g., stethoscopes, doorknobs), including Staph. aureus (21.7\% frequency), Staph. epidermis (8.7\%), Streptococcus spp. (8.7\%), Bacillus spp. (13.0\%), E. coli (26.1\%), Pseudomonas spp. (8.7\%) and Klebsiella spp. (13.0\%) (Maryam et al., 2014). There has also been a rapid increase in the incidence of infections with drug-resistant microorganisms acquired by patients while in the hospital. Bacterial human skin infection strains are correlated with nosocomial infection, fomites and antimicrobial-resistant strains. Obtaining new antimicrobial agents from natural resources is necessary to develop alternative drugs for safe and cost-effective health care.

Chromolaena odorata (L.) R. M. King and H. Robinson is a weed that is widely found in tropical Africa, North America, and South and Southeast Asia. Common names are Siam weed, Christmas bush, and common floss flower (Chakraborty, Rambhade, \& Patil, 2011; Queensland Department of Agriculture, Fisheries and Forestry, 2013). Previous studies have reported that this plant exhibits biological activities: antimicrobial activity (Suksamrarn et al., 2004; Pisutthanan et al., 2005; Vital \& Rivera, 2009; Naidoo, Coopoosamy, \& Naidoo, 2011; Sukanya, Sudisha, Prakash, \& Fathima, 2011; Mondal, Bhargava, Shivapuri, \& Kar, 2012; Atindehou et al., 2013; Eze, Oruche, Onuora, \& Eze, 2013; Kigigha \& Zige, 2013; Stanley, Ifeanyi, Nwakaego, \& Esther, 2014); antibiofilm activity (Yahya, Ibrahim, Zawawi, \& Hamid, 2014); antihepatotoxicity (Alisi, Onyeze, Ojiako, \& Osuagwu, 2014; Asomugha, Okafor, Ijeh, Orisakwe, \& Asomugha 2014); antimalarial activity (Pisutthanan et al., 2005); anthelmintic activity (Vital \& Rivera, 2009); antiviral activity (Pisutthanan et al., 2005); phytopathogenic activity (Sukanya et al., 2009); antiprotozoal activity (Vital \& Rivera, 2009); wound healing (Anyasor, Aina, Olushola, \& Aniyikaye, 2011); and antioxidant activity (Akinmoladun, Ibukun, \& Dan Ologe, 2007). Chemical compounds produced by this plant play a role in inhibiting the growth of pathogenic microorganisms: leaf extract contains coumarins, tannins, steroids, saponins, terpenoids, terpenes, flavonoids and cardiac glycosides (Phan et al., 2001; Akinmoladun et al., 2007; Vital \& Rivera, 2009; Anyasor et al., 2011; Lavanya \& Brahmaprakash, 2011); flower extract contains flavonoids (isosakuranetin, persicogenin, 5,6,7,4'-tetramethoxyflavanone and 4'-hydroxy-5,6,7-trimethoxyflavanone) and flavones (acacetin and luteolin) (Suksamrarn et al., 2004); root extract contains triterpenes, poriferasterol, octadecane, butyrospermol acetate, bis(2-ethylhexyl) phthalate, chrysophanol and physcion (Amatya \& Tuladhar, 2005); while stem extract has not been studied. The factors affecting the biological activity of medicinal plants are the plant part, season, climate, growth phase, extraction solvent, extraction procedure, and plant material to solvent ratio (Maji et al., 2010; Kothari, Gupta, \& Naraniwal, 2012). Many researchers have reported that effective antimicrobial compounds have been obtained from the plant leaf, but there are few reports on other plant parts.

Previous studies on the antibacterial activity of this plant extract have been limited to clinical diarrheal strains such as B. cereus, E. coli, Kleb. oxytoca, Salmonella enterica, Salmonella Typhimurium, Shigella sonnei and Vibrio cholera, and skin infections with bacteria such as Staph. aureus and Staph. epidermidis (Vital \& Rivera, 2009; Maji et al., 2010; Naidoo et al., 2011; Atindehou et al., 2013; Eze et al., 2013). A few reports have investigated the effect of $C$. odorata extract on bacterial human skin infection strains.

In this study, we investigated the antibacterial activity of $C$. odorata extracts against bacterial human skin infection strains. Various parts of $C$. odorata, i.e. leaf, stem and root, were extracted with water, ethanol, methanol and hexane. Antibiotics extracted from medicinal plants are an alternative method to reduce the antibiotic resistance of bacterial pathogens.

\section{Method}

\subsection{Plant Extraction}

Leaf, stem and root parts were collected from $C$. odorata plants in Amnat Charoen province, Thailand. Each plant part was washed, dried in sunlight, and then placed in a hot-air oven with temperature controlled at $60{ }^{\circ} \mathrm{C}$. Dried plant parts were then collected, blended and weighed before extraction. A $3 \times 4$ factorial design was employed on the $C$. odorata extracts, giving an output of 12 experiments. Twenty g of dried plant part powder was soaked in a $500 \mathrm{~mL}$ conical flask containing $200 \mathrm{~mL}$ of water, $95 \%$ ethanol, methanol or hexane solvents, and shaken on a vertical shaker at $150 \mathrm{rpm}$ for $24 \mathrm{~h}$. The extract solutions were filtered through Whatman filter paper No. 1. The filtrates were concentrated by evaporation (R-200 rotary evaporator; Büchi, Flawil, Switzerland) and frozen in a freeze dryer (CoolSafe; Labogene, Lynge, Denmark). Crude extract powder was stored at $4{ }^{\circ} \mathrm{C}$ until used. The percentage yield of crude extract powder was calculated by the following equation:

$$
\text { Percentage yield }=\frac{\text { Extract weight }}{\text { Dried plant weight }} \times 100
$$




\subsection{Determination of Total Phenols and Total Flavonoids by HPLC-DAD Method}

The content of total phenols and flavonoids was analyzed by high-performance liquid chromatography (HPLC) (LC-20AD; Shimadzu, Kyoto, Japan) using a UV-vis diode array detector (DAD) recording at 280 and $360 \mathrm{~nm}$ (SPD-M20A, variable wavelength; Shimadzu) (Peñarrieta, Alvarado, Bergenstahl \& Akesson, 2007). The conditions of phytochemical analysis were set as follows: mobile phase (methanol: $1 \%$ acetic acid), retention time $(20 \mathrm{~min})$, and flow rate $(0.8 \% \mathrm{~mL} / \mathrm{min})$. The analytical column used in this study was an Intersil ${ }^{\circledR}$ ODS-3, size $4.6 \times 150 \mathrm{~mm}$ (GL Sciences, Tokyo, Japan). Gallic acid and Trolox were used as standards for phenolic contents, and rutin and quercetin for flavonoid contents.

\subsection{Pathogenic Bacteria}

The pathogenic bacteria used to test the antimicrobial activity of the plant extracts were six strains of gram-positive bacteria (B. cereus TISTR 687, Entc. faecalis TISTR 379, Staph. epidermidis TISTR 518, Staph. aureus TISTR 1466, Strep. pyogenes ATCC 19615 and Prop.acnes DMST 14916) and five strains of gram-negative bacteria (Entb. aerogenes ATCC 13048, E. coli TISTR 780, Kleb. pneumoniae TISTR 1843, Pr. vulgaris ATCC 13315 and Ps. aeruginosa ATCC 27853). All tested bacteria were grown on trypticase soy broth (TSB) (Himedia, Mumbai, India) and incubated at $35 \pm 2{ }^{\circ} \mathrm{C}$ for $18-24 \mathrm{~h}$ before use, except Entc. faecalis TISTR 379 was incubated under anaerobic conditions.

\subsection{Antibacterial Activity Assay}

\subsubsection{Determination of Inhibition Zone of Crude Extracts by Agar Well Diffusion}

The inhibition zone was determined using agar well diffusion method. Twenty-eight $\mathrm{mL}$ of trypticase soy agar (TSA) was poured into individual Petri dishes until the media became solid. One loop of each strain taken from each working stock was incubated on a TSA plate with $5 \mathrm{~mL}$ of trypticase soy broth (TAB) at $35 \pm 2{ }^{\circ} \mathrm{C}$ for 18 $24 \mathrm{~h}$, except Entc. faecalis TISTR 379 was incubated under anaerobic conditions. Bacterial strain cultures were adjusted to obtain a final concentration of $10^{8} \mathrm{CFU} / \mathrm{mL}$ using a $0.5 \mathrm{McFarland}$ standard. One hundred $\mu 1$ of the optimum cell concentration was then swabbed on a TSA plate by three-way method. Wells ( $7 \mathrm{~mm}$ diameter) were cut into the agar plates using a sterile cork borer (No. 3). About $100 \mu 1$ of extract from each plant part was poured into individual wells. Stock solutions of the extracts were prepared at a final concentration of $100 \mathrm{mg} / \mathrm{mL}$. DMSO (dimethyl sulfoxide, 10\%) was used as a negative control. The agar well plate was then incubated for 18 $24 \mathrm{~h}$ at $35 \pm 2{ }^{\circ} \mathrm{C}$. Antimicrobial activity was measured in terms of the diameter of the inhibition zone (mm). A value of the inhibition zone of $\geq 10 \mathrm{~mm}$ was selected to study the minimum inhibitory concentration (MIC) and minimum bactericidal concentration (MBC).

\subsubsection{Determination of Bacterial Susceptibility to Extracts by MIC and MBC}

The MIC and MBC were determined by two-fold serial dilution method using a macro-broth dilution technique modified from Schwalbe, Steele-Moore \& Goodwin (2007). A stock solution $(100 \mathrm{mg} / \mathrm{mL})$ of each extract was serially two-fold diluted in a tube with $1 \mathrm{~mL}$ TSB to obtain concentrations ranging from $0 \mathrm{mg} / \mathrm{mL}$ to $100 \mathrm{mg} / \mathrm{mL}$. The zero concentration $(0 \mathrm{mg} / \mathrm{mL})$ tube served as a growth control. The inoculum size was prepared by diluting cell cultures in TSB to obtain a cell concentration of $10^{8} \mathrm{CFU} / \mathrm{mL}$ using $0.5 \mathrm{McF}$ arland standard and then diluting with TSB to obtain a cell concentration of $10^{6} \mathrm{CFU} / \mathrm{mL}$. Then $0.1 \mathrm{~mL}$ of each standard inoculum was added to the diluted extracts. Cultivation was carried out at $35 \pm 2{ }^{\circ} \mathrm{C}$ for $18-20 \mathrm{~h}$. The reduction of bacterial growth in each tube, containing various extract concentrations, was determined using a standard plate count compared with the growth control tube. MIC was defined as $80 \%$ inhibition in growth of the initial bacterial inoculum when compared with the control. MBC was defined the lowest concentration of a plant extract that killed the majority (99.9\%) of the initial bacterial inoculum.

\subsection{Statistical Analysis}

Data were subjected to one-way analysis of variance (ANOVA) using SPSS Statistics 17.0 (SPSS, USA). The different treatments were analyzed using Duncan's multiple range test method at a confidence level of 95\%.

\section{Results}

\subsection{Extraction Yield}

Twelve samples of $C$. odorata extracts were obtained from leaf, stem and root plant parts, and were used for water, ethanol, methanol and hexane extractions, as shown in Table 1. Leaf extracts gave significantly higher 
percentage yields than stem and root extracts for all extraction solvents. The water and methanol solvents showed significantly higher yields compared with the other extraction solvents for the plant leaf and stem, but not the root. The lowest percentage yield was obtained from $C$. odorata root extracted with hexane solvent. Furthermore, hexane solvent gave a significantly lower percentage yield for all plant parts compared with water, ethanol and methanol solvents.

Table 1. Extraction yields of leaf, stem and root of C. odorata with four different solvents

\begin{tabular}{|c|c|c|c|c|c|c|c|}
\hline \multirow[t]{2}{*}{ Plant parts } & \multirow[t]{2}{*}{ Extraction solvents } & \multicolumn{5}{|c|}{ Extractive value } & \multirow[t]{2}{*}{$\% \mathrm{CV}$} \\
\hline & & $\begin{array}{c}\text { Repeat } 1 \\
(\mathrm{~g} / 10 \mathrm{~g})\end{array}$ & $\begin{array}{c}\text { Repeat } 2 \\
(\mathrm{~g} / 10 \mathrm{~g})\end{array}$ & $\begin{array}{c}\text { Repeat } 3 \\
(\mathrm{~g} / 10 \mathrm{~g})\end{array}$ & $\begin{array}{c}\text { Average } \\
(\mathrm{g} / 10 \mathrm{~g})\end{array}$ & Yield (\%) & \\
\hline \multirow[t]{4}{*}{ Leaf } & Water & 1.38 & 1.19 & 1.08 & 1.22 & $12.16 \pm 0.134_{\mathrm{c}}^{\mathrm{a}}$ & \multirow[t]{4}{*}{47.51} \\
\hline & Ethanol & 0.10 & 0.83 & 0.70 & 0.84 & $8.42 \pm 0.115^{b}{ }_{c}$ & \\
\hline & Methanol & 1.06 & 1.04 & 1.03 & 1.05 & $10.45 \pm 0.012^{\mathrm{a}} \mathrm{b}$ & \\
\hline & Hexane & 0.21 & 0.24 & 0.27 & 0.24 & $2.37 \pm 0.21_{\mathrm{b}}^{\mathrm{c}}$ & \\
\hline \multirow[t]{4}{*}{ Stem } & Water & 0.32 & 0.24 & 0.19 & 0.25 & $2.49 \pm 0.057_{\mathrm{b}}^{\mathrm{a}}$ & \multirow[t]{4}{*}{58.33} \\
\hline & Ethanol & 0.18 & 0.18 & 0.20 & 0.19 & $1.88 \pm 0.004_{\mathrm{b}}^{\mathrm{b}}$ & \\
\hline & Methanol & 0.29 & 0.27 & 0.34 & 0.30 & $2.99 \pm 0.007_{\mathrm{a}}^{\mathrm{a}}$ & \\
\hline & Hexane & 0.02 & 0.03 & 0.03 & 0.03 & $0.28 \pm 0.009^{c}{ }_{a}$ & \\
\hline \multirow[t]{4}{*}{ Root } & Water & 0.56 & 0.65 & 0.56 & 0.59 & $5.87 \pm 0.063^{\mathrm{a}}{ }_{\mathrm{a}}$ & \multirow[t]{4}{*}{58.78} \\
\hline & Ethanol & 0.41 & 0.39 & 0.40 & 0.40 & $3.99 \pm 0.015^{\mathrm{b}} \mathrm{a}$ & \\
\hline & Methanol & 0.32 & 0.41 & 0.57 & 0.43 & $4.34 \pm 0.068_{\mathrm{a}}^{\mathrm{b}}$ & \\
\hline & Hexane & 0.04 & 0.07 & 0.02 & 0.05 & $0.46 \pm 0.023_{\mathrm{a}}^{\mathrm{c}}$ & \\
\hline$\% \mathrm{CV}$ & & 90.38 & 82.21 & 78.37 & & & \\
\hline
\end{tabular}

Note. $\% \mathrm{CV}=$ percent coefficient of variation.

Superscript letters within a column indicate significant $(\mathrm{p}<0.05)$ differences of means within solvents. Subscript letters within a column indicate significant $(\mathrm{p}<0.05)$ differences of means within plant parts. Statistics analyzed using Duncan's multiple range test.

\subsection{Content of Total Phenols and Flavonoids}

Evaluation of total phenolic and flavonoid contents was determined for three plant parts and four solvents, as shown in Table 2. The maximum content of total phenols was found in the ethanol leaf extract, followed by water, methanol and hexane. For the stem, water extract contained the highest total phenols. The highest flavonoid contents were found in the ethanol leaf extract, compared with other plant parts and solvents. The ethanol leaf extract also had the highest total phenolic and flavonoid contents, followed by water and methanol; hexane leaf extract only contained phenols.

\subsection{Antibacterial Activity}

Leaf extracts in ethanol, methanol and hexane exhibited strong inhibitory effects against $B$. cereus TISTR 687, Entc. faecalis TISTR 379, Staph. epidermidis TISTR 518, Staph. aureus TISTR 1466, Strep. pyogenes ATCC 19615 and Prop. acnes DMST 14916, with inhibition zones in the ranges of $14.6 \pm 0.6$ to $20.0 \pm 0.5,14.7 \pm 1.5$ to $17.0 \pm 1.0,11.2 \pm 1.4$ to $14.7 \pm 1.5,12.0 \pm 0.5$ to $20.3 \pm 0.6,15.7 \pm 0.6$ to $20.3 \pm 2.9$, and $9.7 \pm 0.6$ to $14.2 \pm$ $0.8 \mathrm{~mm}$, respectively. In gram-negative bacteria, the ethanol, methanol and hexane leaf extracts affected Ps. aeruginosa ATCC 27853, with inhibition zones ranging from $12.5 \pm 0.3$ to $15.3 \pm 0.5 \mathrm{~mm}$. Pr. vulgaris ATCC 13315 was inhibited by the leaf extracts in all solvents. Methanol and hexane leaf extracts also showed antimicrobial activity against Kleb.pneumoniae TISTR 1843, while the water, ethanol and methanol extracts only had an effect against $E$. coli TISTR 780. None of the plant extracts were effective against Entb. aerogenes ATCC 13048. Hexane extract of the stem of $C$. odorata showed inhibitory activity against $B$. cereus TISTR 687, Entc. faecalis TISTR 379, Staph. epidermidis TISTR 518, Strep. pyogenes ATCC 19615, Kleb. pneumoniae TISTR 1843, Pr. vulgaris ATCC 13315 and Ps. aeruginosa ATCC 27853, while the root extract also exhibited inhibitory activity against all of the above except for B. cereus TISTR 687 and Pr. vulgaris ATCC 13315. Furthermore, the ethanolic stem and water root extracts showed inhibitory activity against Strep. pyogenes ATCC 19615 and E. coli TISTR 780, respectively (Table 3, 4 and 5 and Figures 1 and 2). 
Table 2. Phytochemical analysis of leaf, stem and root of C. odorata extracted using different solvents

\begin{tabular}{llllcccc}
\hline $\begin{array}{l}\text { Plant } \\
\text { parts }\end{array}$ & Solvents & \multicolumn{3}{c}{ Phenols } & & Flavonoids \\
\cline { 2 - 7 } & & $\begin{array}{c}\text { Gallic acid } \\
\text { (mg of } \\
\text { GA/g of } \\
\text { dry extract) }\end{array}$ & $\begin{array}{c}\text { Trolox } \\
\text { (mg of TL } \\
\text { /g of dry } \\
\text { extract) }\end{array}$ & $\begin{array}{c}\text { Total phenols } \\
\text { (mg of GA } \\
\text { and TL/g of } \\
\text { dry extract) }\end{array}$ & $\begin{array}{c}\text { Quercetin } \\
\text { (mg of QC/g } \\
\text { of dry } \\
\text { extract) }\end{array}$ & $\begin{array}{c}\text { Rutin } \\
\text { (mg of } \\
\text { RU/g of } \\
\text { dry extract) }\end{array}$ & $\begin{array}{c}\text { Total } \\
\text { flavonoids } \\
\text { (mg of QC and } \\
\text { RU/g of dry } \\
\text { extract) }\end{array}$ \\
\hline Leaf & Water & 3.42 & 1.06 & 4.48 & ND & 2.52 & 2.25 \\
& Ethanol & 1.54 & 4.74 & 4.74 & 0.31 & 9.85 & 10.16 \\
& Methanol & 2.20 & 0.23 & 2.43 & ND & 2.64 & 2.64 \\
& Hexane & ND & 2.81 & 2.81 & ND & ND & ND \\
& Water & 3.83 & ND & 3.83 & ND & ND & ND \\
& Ethanol & 1.51 & 0.98 & 2.49 & ND & ND & ND \\
& Methanol & 1.61 & ND & 1.61 & ND & ND & ND \\
& Hexane & 0.05 & 0.34 & 0.39 & 0.002 & 0.01 & 0.012 \\
& Water & 1.85 & 0.66 & 2.51 & 0.34 & 1.19 & 1.53 \\
& Ethanol & 1.55 & 0.10 & 1.65 & ND & ND & ND \\
& Methanol & 0.99 & 0.19 & 1.18 & 0.06 & 0.77 & 0.83 \\
& Hexane & 1.85 & 0.49 & 2.34 & ND & 0.04 & 0.04 \\
\hline
\end{tabular}

Note. $\mathrm{ND}=$ Not detected.

Table 3. Antibacterial activity (zone of inhibition, $\mathrm{mm}$ ) of $C$. odorata leaf extract

\begin{tabular}{lcccc}
\hline Tested microorganisms & \multicolumn{4}{c}{ Diameter of inhibition zone $(\mathrm{mm})^{*}$} \\
\cline { 2 - 5 } & Water & Ethanol & Methanol & Hexane \\
\hline Gram-positive bacteria & & & & \\
B. cereus TISTR 687 & NI & $15.3 \pm 0.6$ & $19.3 \pm 0.6$ & $20.7 \pm 0.5$ \\
Entc. faecalis TISTR 379 & NI & $14.7 \pm 1.5$ & $16.0 \pm 1.5$ & $17.0 \pm 1.0$ \\
Staph. epidermidis TISTR 518 & NI & $13.0 \pm 1.0$ & $12.7 \pm 2.5$ & $14.7 \pm 1.5$ \\
Staph. aureus TISTR 1466 & NI & $16.0 \pm 0.5$ & $20.3 \pm 0.6$ & $12.0 \pm 0.5$ \\
Strep. pyogenes ATCC 19615 & NI & $15.7 \pm 0.6$ & $16.0 \pm 1.7$ & $20.3 \pm 2.9$ \\
Prop. acnes DMST 14916 & NI & $9.7 \pm 0.6$ & $9.7 \pm 0.6$ & $14.2 \pm 0.8$ \\
Gram-negative bacteria & & & & \\
Entb. aerogenes ATCC 13048 & NI & NI & NI & NI \\
E. coli TISTR 780 & $13.3 \pm 1.3$ & $10.7 \pm 0.6$ & $13.7 \pm 0.6$ & NI \\
Kleb. pneumoniae TISTR 1843 & NI & NI & $13.7 \pm 0.6$ & $12.7 \pm 0.6$ \\
Pr. vulgaris ATCC 13315 & $10.5 \pm 0.0$ & $11.5 \pm 0.5$ & $13.3 \pm 0.0$ & $15.0 \pm 0.5$ \\
Ps. aeruginosa ATCC 27853 & NI & $12.5 \pm 0.3$ & NI & NI \\
\hline
\end{tabular}

Note. $\mathrm{NI}=$ no inhibition; ${ }^{*}=$ included diameter of cork borer $(7 \mathrm{~mm})$.

Table 4. Antibacterial activity (zone of inhibition, $\mathrm{mm}$ ) of $C$. odorata stem extract

\begin{tabular}{ccccc}
\hline Tested microorganisms & \multicolumn{4}{c}{ Diameter of inhibition zone $(\mathrm{mm})^{*}$} \\
\cline { 2 - 4 } & Water & Ethanol & Methanol & Hexane \\
\hline
\end{tabular}

Gram-positive bacteria 


\begin{tabular}{lcccc} 
B. cereus TISTR 687 & NI & NI & NI & $14.6 \pm 0.58$ \\
Entc. faecalis TISTR 379 & NI & NI & NI & $14.7 \pm 0.6$ \\
Staph. epidermidis TISTR 518 & NI & NI & NI & $11.5 \pm 1.8$ \\
Staph. aureus TISTR 1466 & NI & NI & NI & NI \\
\hline Strep. pyogenes ATCC 19615 & NI & $10.3 \pm 0.6$ & $10.7 \pm 0.6$ & $14.3 \pm 2.9$ \\
Prop. acnes DMST 14916 & NI & NI & NI & NI \\
Gram-negative bacteria & & & & \\
Entb. aerogenes ATCC 13048 & NI & NI & NI & NI \\
E. coli TISTR 780 & NI & NI & NI & NI \\
Kleb. pneumoniae TISTR 1843 & NI & NI & NI & $14.0 \pm 1.0$ \\
Pr. vulgaris ATCC 13315 & NI & NI & NI & $12.5 \pm 0.5$ \\
Ps. aeruginosa ATCC 27853 & NI & NI & NI & $15.3 \pm 0.5$ \\
\hline
\end{tabular}

Note. $\mathrm{NI}=$ no inhibition; ${ }^{*}=$ included diameter of cork borer $(7 \mathrm{~mm})$.

Table 5. Antibacterial activity (zone of inhibition, $\mathrm{mm}$ ) of $C$. odorata root extract

\begin{tabular}{lcccc}
\hline \multirow{2}{*}{ Tested microorganisms } & \multicolumn{4}{c}{ Diameter of inhibition zone $(\mathrm{mm})^{*}$} \\
\cline { 2 - 5 } & Water & Ethanol & Methanol & Hexane \\
\hline Gram-positive bacteria & & & & \\
B. cereus TISTR 687 & NI & NI & NI & NI \\
Entc. faecalis TISTR 379 & NI & NI & NI & $14.5 \pm 0.9$ \\
Staph. epidermidis TISTR 518 & NI & NI & NI & $11.2 \pm 1.4$ \\
Staph. aureus TISTR 1466 & NI & NI & NI & NI \\
Strep. pyogenes ATCC 19615 & NI & NI & NI & $11.7 \pm 0.6$ \\
Prop. acnes DMST 14916 & NI & NI & NI & NI \\
Gram-negative bacteria & & & & \\
Entb. aerogenes ATCC 13048 & NI & NI & NI & NI \\
E. coli TISTR 780 & $12.7 \pm 0.6$ & NI & NI & NI \\
Kleb. pneumoniae TISTR 1843 & NI & NI & NI & $14.7 \pm 0.6$ \\
Pr. vulgaris ATCC 13315 & NI & NI & NI & NI \\
Ps. aeruginosa ATCC 27853 & NI & NI & NI & NI \\
\hline
\end{tabular}

Note. $\mathrm{NI}=$ no inhibition; $*$ = included diameter of cork borer $(7 \mathrm{~mm})$.

The ethanolic leaf extract was found to be more active against Staph. aureus TISTR 1466, with a MIC of 0.81 $\mathrm{mg} / \mathrm{mL}(\mathrm{MBC}=1.62 \mathrm{mg} / \mathrm{mL})$, followed by methanolic and hexane leaf extracts, which exhibited inhibitory activity against Staph. aureus TISTR 1466 and Strep. pyogenes ATCC 19615, with an MIC equal to $1.65 \mathrm{mg} / \mathrm{mL}$. The hexane root extract had the lowest activity, while hexane stem extract showed inhibitory activity against $B$. cereus TISTR $687(\mathrm{MIC}=6.25 \mathrm{mg} / \mathrm{mL})$ and Pr. vulgaris ATCC $13315(\mathrm{MIC}=6.25 \mathrm{mg} / \mathrm{mL})$. C. odorata extracts were most active against Staph. aureus TISTR 1466, followed by Strep. pyogenes ATCC 19615, Staph. epidermidis TISTR 518 and Prop. acnes DMST 14916; while for gram-negative bacteria, C. odorata extracts showed inhibitory activity against only Pr. vulgaris ATCC 13315 (Table 6,7 and 8). Previous reports found that methanol leaf extract from $C$. odorata obtained in Nigeria gave a MIC value against Staph. aureus in a range of $0.125-2.0 \mathrm{mg} / \mathrm{mL}$, a MIC value which closely matched our results (Eze et al., 2013; Stanley et al., 2014). However, our results indicated that the methanolic leaf extract of $C$. odorata $(6.25 \mathrm{mg} / \mathrm{mL})$ had a better MIC against Staph. epidermidis TISTR 518 than the methanolic leaf extract from C. odorata grown in Durban, South Africa $(8.0 \mathrm{mg} / \mathrm{mL})$ (Naidoo et al., 2011). Furthermore, the results obtained suggest that the extracts of $C$. odorata exhibited better antibacterial activity against gram-positive bacteria than gram-negative bacteria. The outer phospholipid membrane of gram-negative bacteria has lipopolysaccharide (LPS) components, making it impermeable to lipophilic solutes. The cell wall of gram-positive bacteria has only an outer peptidoglycan layer, which is not an effective permeability barrier (Vital \& Rivera, 2009).

Table 6. Antibacterial activity (MIC and MBC values, $\mathrm{mg} / \mathrm{mL}$ ) of C. odorata leaf extract

$\begin{array}{llll}\text { Tested microorganisms } & \text { Water } & \text { Ethanol } & \text { Methanol Hexane }\end{array}$


Note. $\mathrm{ND}=$ not determined.

\begin{tabular}{lcccccccc} 
& MIC & MBC & MIC & MBC & MIC & MBC & MIC & MBC \\
\hline Gram-positive bacteria & & & & & & & & \\
B. cereus TISTR 687 & ND & ND & 12.5 & 25.0 & 12.5 & 25 & 6.25 & 12.5 \\
Entc. faecalis TISTR 379 & ND & ND & 12.5 & 25 & 12.5 & 25 & 12.5 & 25 \\
Staph. epidermidis TISTR 518 & ND & ND & 6.25 & 12.5 & 6.25 & 12.5 & 6.25 & 12.5 \\
Staph. aureus TISTR 1466 & ND & ND & 0.81 & 1.62 & 1.62 & 3.25 & 1.62 & 3.25 \\
Strep. pyogenes ATCC 19615 & ND & ND & 3.25 & 6.25 & 1.62 & 3.25 & 1.62 & 3.25 \\
Prop. acnes DMST 14916 & ND & ND & 12.5 & 25 & 12.5 & 25.0 & 6.25 & 12.5 \\
Gram-negative bacteria & & & & & & & & \\
E. coli TISTR 780 & 25 & 50 & 25 & 50 & 25 & 50 & ND & ND \\
Kleb. pneumoniae TISTR 1843 & ND & ND & ND & ND & 25 & 50 & 12.5 & 25 \\
Pr. vulgaris ATCC 13315 & 25 & 50 & 6.25 & 12.5 & 6.25 & 12.5 & 6.25 & 12.5 \\
Ps. aeruginosa ATCC 27853 & ND & ND & 12.5 & 25.0 & ND & ND & ND & ND \\
\hline
\end{tabular}

Table 7. Antibacterial activity (MIC and MBC values, $\mathrm{mg} / \mathrm{mL}$ ) of C. odorata stem extract

\begin{tabular}{lcccccc}
\hline \multicolumn{1}{c}{ Tested microorganisms } & \multicolumn{2}{c}{ Ethanol } & \multicolumn{2}{c}{ Methanol } & \multicolumn{2}{c}{ Hexane } \\
\cline { 2 - 7 } & MIC & MBC & MIC & MBC & MIC & MBC \\
\hline Gram-positive bacteria & & & & & & \\
B. cereus TISTR 687 & ND & ND & ND & ND & 6.25 & 12.5 \\
Entc. faecalis TISTR 379 & ND & ND & ND & ND & 12.5 & 25 \\
Staph. epidermidis TISTR 518 & ND & ND & ND & ND & 25 & 50 \\
Strep. pyogenes ATCC 19615 & 25 & 50 & 25 & 50 & 25 & 50 \\
Gram-negative bacteria & & & & & & \\
Kleb. pneumoniae TISTR 1843 & ND & ND & ND & ND & 12.5 & 25 \\
Pr. vulgaris ATCC 13315 & ND & ND & ND & ND & 6.25 & 12.5 \\
Ps. aeruginosa ATCC 27853 & ND & ND & ND & ND & 25.0 & 50.0 \\
\hline
\end{tabular}

Note. $\mathrm{ND}=$ not determined.

Table 8. Antibacterial activity (MIC and MBC values, $\mathrm{mg} / \mathrm{mL}$ ) of $C$. odorata root extract

\begin{tabular}{lcccc}
\hline \multirow{2}{*}{ Tested microorganisms } & \multicolumn{2}{c}{ Water } & \multicolumn{2}{c}{ Hexane } \\
\cline { 2 - 5 } & MIC & MBC & MIC & MBC \\
\hline Gram-positive bacteria & & & & \\
Entc. faecalis TISTR 379 & ND & ND & 12.5 & 25 \\
Staph. epidermidis TISTR 518 & ND & ND & 25 & 50 \\
Strep. pyogenes ATCC 19615 & ND & ND & 25 & 50 \\
Gram-negative bacteria & & & & \\
E. coli TISTR 780 & 25 & 50 & ND & ND \\
Kleb. pneumoniae TISTR 1843 & ND & ND & 12.5 & 25 \\
\hline
\end{tabular}

Note. $\mathrm{ND}=$ not determined.

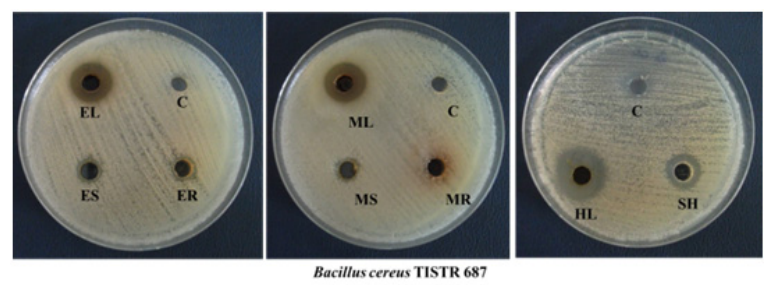



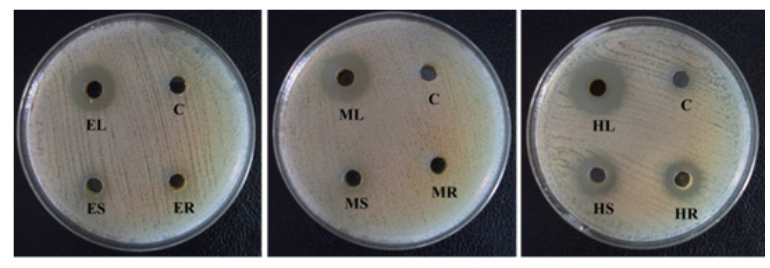

Enterococcusfaecalis TISTR 379
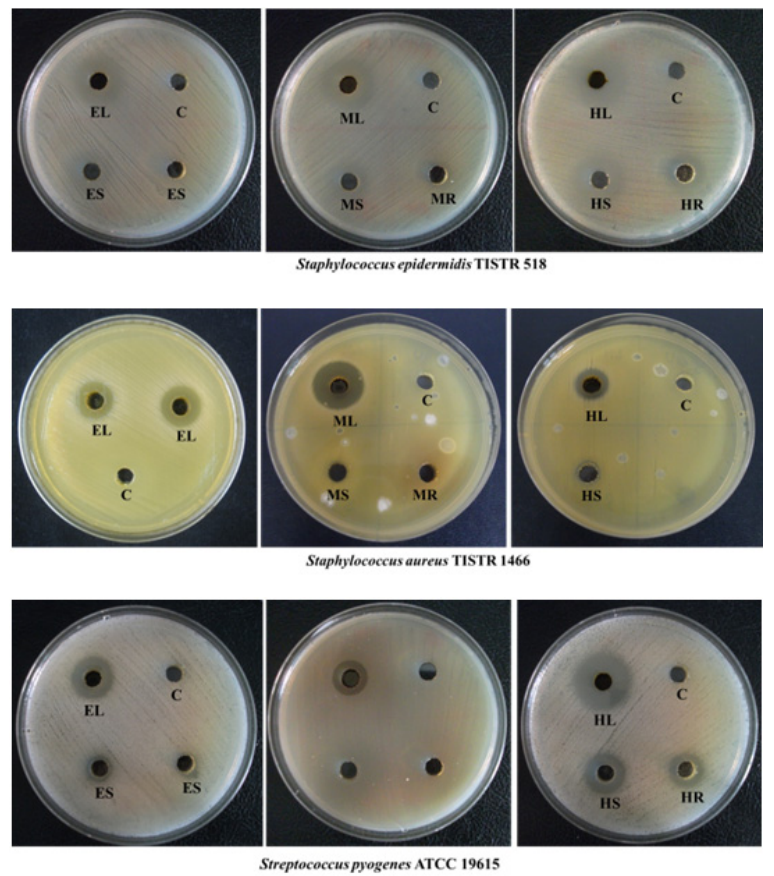

Streptococcus pyogenes ATCC 19615
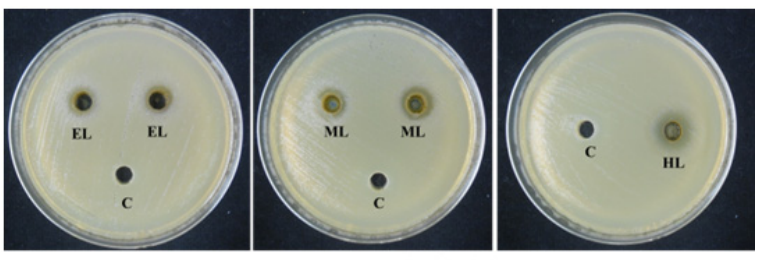

Figure 1. Inhibitory activity of some $C$. odorata extracts against gram-positive bacteria C, 10\% DMSO; EL, Ethanol leaf; ES, ethanol stem; ER, ethanol root; ML,Methanol leaf; MS, Methanol stem; MR, Methanol root; HL, Hexane leaf; HS, Hexane stem; HR, Hexane root

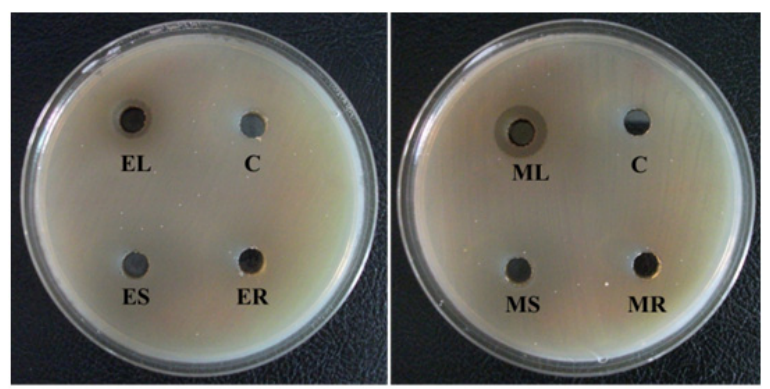

Escherichia coli TISTR 780 


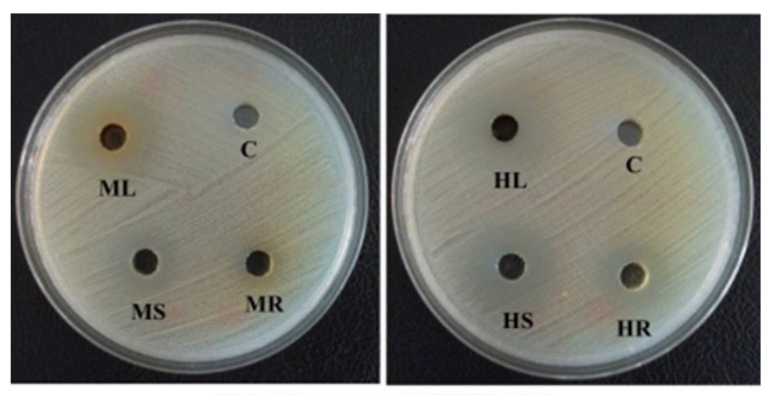

Klebseilla pneumonia TISTR 1843
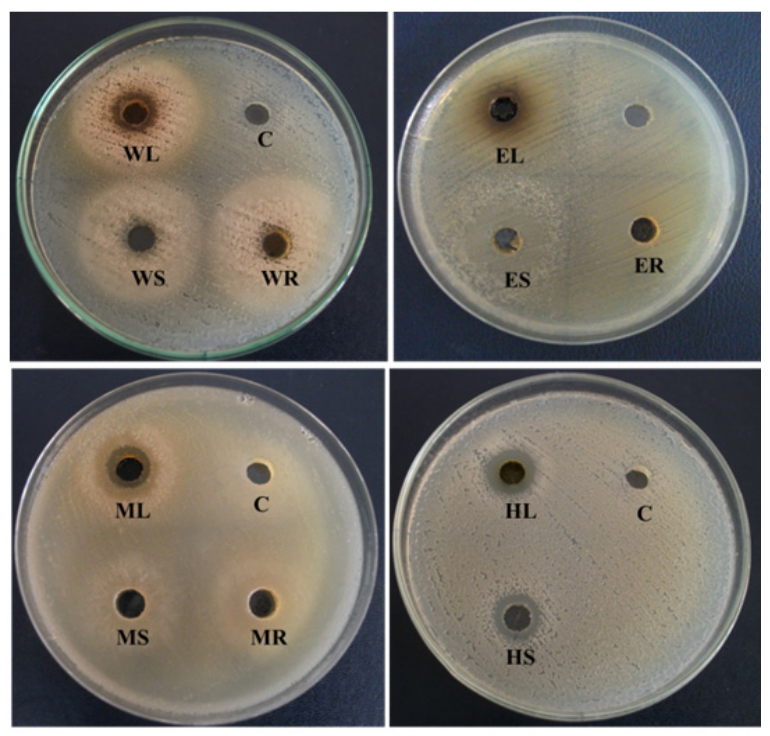

Proteus vulgaricus ATCC 13315
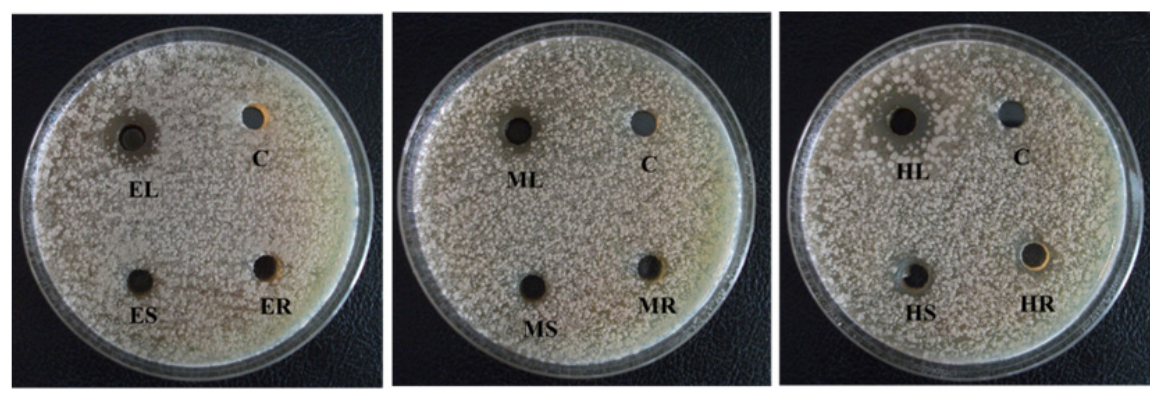

Pseudomonas aeruginosa ATC53C 278

Figure 2. Inhibitory activity of some $C$. odorata extracts against gram-negative bacteria $\mathrm{C}, 10 \% \mathrm{DMSO}$; EL, Ethanol leaf; ES, ethanol stem; ER, ethanol root; ML, Methanol leaf; MS, Methanol stem; MR, Methanol root; HL, Hexane leaf; HS, Hexane stem; HR, Hexane root

\section{Discussion}

\subsection{Effect of Solvents and Plant Parts on Yields and Compounds of C. Odorata Extracts}

Our results indicated that water and methanol showed the highest percentage yield, followed by ethanol and hexane, when using a 1:10 (w/v) ratio of dried plant material and solvent. The effects on antibacterial activity were associated with the plant part and extraction solvent. The leaf was absorbed by polar organic solvents more than the other plant parts. These results were similar to the report of Stanley et al. (2014) but different from Mondal et al. (2012). The hexane extract of $C$. odorata gave the lowest yield which similar to the reported of Kusuma et al. (2014). Hexane is a low-polarity solvent, which can dissolve and separate the non-polar secondary compounds from the plants such as tannins, terpenes and quinines (Lavanya \& Brahmaprakash, 2011; Delahaye et al., 2009). The extraction efficiency from plants is related to solvent type, plant material to solvent ratio, time of extraction, and particle sizes of the plant (Tiwari, Kumar, M. Kaur, G. Kaur, \& H. Kaur, 2011). The rate of 
extraction can be increased by increasing the surface area and using a sample to solvent ratio of 1:10 (w/v) (Tiwari et al., 2011).

Total phenolic contents were found in almost all previous reports on C. odorata leaf extracts. Interestingly, in several studies no flavonoid contents were discovered during phytochemical screening (Anyasor et al., 2011; Danlami et al., 2013). However, Mondal et al. (2012) reported on the flavonoid contents found in C. odorata leaf extract but not the total phenolic contents. In the present study, only ethanol leaf extract showed higher flavonoid content (rutin) than total phenol contents.

Our results indicated that the water, ethanol and methanol leaf extracts of $C$. odorata possessed antibacterial activity, as they exhibited the highest total phenol and flavonoid contents (Table 4). Both ethanol and methanol solvents could extract antimicrobial compounds (flavonoids, flavones, polyphenols, terpenes and tannins) from the leaf of $C$. odorata (Akinmoladun et al., 2007; Tiwari et al., 2011; Mondal et al., 2012; Vijayaraghavan, Ali, \& Maruthi, 2013; Stanley et al., 2014). Normally, the polarity of a solvent plays a key role in increasing phenolic solubility (Naczk \& Shahidi, 2006). The polar secondary compounds from medical plants contain alkaloids, flavonoid and some phenols (Delahaye et al., 2009). In many plants, the types of flavonoids and phenols that show antimicrobial activity are chrysin, quercetin and rutin, and catechols, epicatechin and cinnamic acid (Tiwari et al., 2011). The antimicrobial compounds of $C$. odorata (flavonoids) are effective at inhibiting the growth of pathogens by binding to the bacterial cell wall, leading to inhibition of cell wall biosynthesis (Anyasor et al., 2011; Lavanya \& Brahmaprakash, 2011). In terms of antibacterial activity, the results indicated that the organic solvents ethanol, methanol and hexane were the most suitable extraction solvents. Highly polar organic solvents such as ethanol and methanol are typically used for extraction of bioactive compounds from plants.

\subsection{Effect of C. Odorata Extracts on Antibacterial Activity}

Our results were similar to previous findings on the effect of $C$. odorata extracts against pathogens. Leaf extracts demonstrated the best antimicrobial activity, followed by stem and root extracts. The best extraction solvent for antibacterial activity was methanol, followed by ethanol and hexane. Most of the antibacterial activities found in the aqueous, ethanol and methanol leaf extracts were against gram-positive bacteria (B. subtilis, B. cereus, Staph. aureus and Staph. epidermidis) and gram-negative bacteria (E. coli, Kleb. pneumoniae, Neisseria gonorrhoeae, Ps. aeruginosa, Salmonella Typhimurium and Vibrio cholerae) (Vital \& Rivera, 2009; Maji et al., 2010; Naidoo et al., 2011; Mondal et al., 2012; Eze et al., 2013; Stanley et al., 2014). Furthermore, it was found that the gram-negative bacteria Entc. aerogenes was not inhibited by water, ethanol, methanol or hexane leaf extracts, results which are in accordance with the leaf extract from C. odorata in Durban, South Africa (Naidoo et al., 2011). E. coli and Klebsiella pneumoniae were inhibited by leaf extracts with acetone and benzene from $C$. odorata in India but not by water leaf extract (Maji et al., 2010). The previous report found that the hexane leaf extacts of Callistemon viminalis leave showed more potent inhibition against skin pathogen (Staph. aureus, Strep. pyogenes and the enteric B. cereus) than intestinal pathogen (Shigella sonnei, Salmonella enteritidis and E. coli) (Delahaye et al., 2009). The factors affecting the quality of plant extracts are the nature of the plant material (season, topography and climate) and its origin (locations) (Tiwari et al., 2011). The type of solvent used in the extraction procedure plays an important role in the diversity of compounds in the plant extracts (Tiwari et al., 2011).

C. odorata stem and root extracts in hexane showed better antibacterial activity compared with other solvents. Venkata et al. (2012) reported that extracts from the root of $C$. odorata, using ethyl alcohol, methanol, chloroform, and methanol:chloroform:water in a ratio of 12:5:3 as solvents, exhibited activity against the same pathogen strains as in our results.

\section{Conclusions}

In comparing the antibacterial activities of different plant parts and extraction solvents, it was found that the most successful extraction procedure for $C$. odorata leaf was by using ethanol and methanol solvents and maceration extraction method. The ethanolic and methanolic leaf extracts gave high extraction yields and high contents of both total phenols and flavonoids. Ethanolic and methanolic leaf extracts also exhibited good antibacterial activity against the gram-positive bacteria Staph. aureus TISTR 1466, Strep. pyogenes ATCC 19615 and Staph. epidermidis TISTR 518 and the gram-negative bacteria Pr. vulgaris ATCC 13315. C. odorata extracts were also more active against gram-positive bacteria than gram-negative bacteria. The antimicrobial activity of $C$. odorata extracts was correlated with the amount of both total phenol and flavonoid compounds. For stem and root parts, hexane solvent was more suitable for extraction of antibacterial compounds than other solvents. This is the first report to demonstrate the antibacterial activity of ethanolic and methanolic leaf extracts of $C$. odorata against Strep. pyogenes ATCC 19615 and Prop. acnes DMST 14916, as well as the inhibitory activity of stem 
extract of C. odorata against the bacterial skin infection (B. cereus TISTR 687, Pr. vulgaris ATCC 13315, Entc. faecalis TISTR 379 and Strep. pyogenes ATCC 19615). The results obtained suggest that the ethanolic and methanolic leaf extracts could be used as a potential natural source for drug development to treat bacterial skin infections.

\section{Acknowledgments}

This work was part of a project financially supported by the National Research Council of Thailand and Suan Dusit University. We would like to gratefully acknowledge Dr. Thongchai Mala for approved the final manuscript. The authors would like to thanks Dr. Suchada Thophon, Dr. Piyaporn Waranusantigul and Dr. Niwat Kangwanrangsan for their help in providing plant materials.

\section{References}

Ahoyo, T. A., Bankolé, H. S., Adéoti, F. M., Gbohoun, A. A., Assavèdo, S., Amoussou Guénou, M., ... Pittet, D. (2014). Prevalence of nosocomial infections and anti-infective therapy in Benin: results of the first nationwide survey in 2012. Antimicrobial Resistance and Infection Control, 3(17), 2-6. Retrieved from http://archive-ouverte.uni

Akinmoladun, A. C., Ibukun, E. O., \& Dan Ologe, I. A. (2007). Phytochemical constituents and antioxidant properties of extracts from the leaves of Chromolaena odorata. Scientific Research and Essay, 2(6), 191-194. Retrieved from http://www.academicjournals.org/SRE

Alisi, C. S., Onyeze, G. O. C., Ojiako, O. A., \& Osuagwu, C. G. (2011). Evaluation of the protective potential of Chromolaena odorata Linn. extract on carbon tetrachloride-induced oxidative liver damage. International Journal of Biochemistry Research and Review, 1(3), 69-81.

Amatya, S., \& Tuladhar, S. M. (2005). Eupatoric acid: a novel triterpene from Eupatorium odorata L. (Asteraceae). Zeitschrift für Naturforschung B, 60, 1006-1011. Retrieved from http://znaturforsch.com/

Anyasor, G. N., Aina, D. A., Olushola, M., \& Aniyikaye, A. F. (2011). Phytochemical constituent, proximate analysis, antioxidant, antibacterial and wound healing properties of leaf extracts of Chromolaena odorata. Annals of Biological Research, 2(2), 441-451. http://dx.doi.org/10.5138/ijpm.v6i2.1390

Asomugha, R. H., Okafor, P. N., Ijeh, I. I., Orisakwe, O. E., \& Asomugha, A. L. (2014). Hepatic effects of aqueous extract of Chromolaena odorata in male Wistar albino rats. Pharmacology Online, 1, 127-136. Retrieved from http://pharmacologyonline.silae.it.

Atindehou, M., Lagnika, L., Guérold, B., Strub, J. M., Zhao, M., Dorsselaer, A. V., ... Metz Boutigue, M. H. (2013). Isolation and identification of two antibacterial agents from Chromolaena odorata L. activity against four diarrheal strains. Advances in Microbiology, 3, 115-121. http://dx.doi.org/10.4236/aim.2013.31018

Chakraborty, A. K., Rambhade, S., \& Patil, U. K. (2011). Chromolaena odorata (L.): an overview. Journal of Pharmacy Research, 4(3), 573-576.

Danlami, U., Adebisi, F. A., David, B. M., Lawal, D. R., \& Galadanchi, K. M. (2013). Proximate and phytochemical analyses of the hexane, ethyl acetate and ethanol extracts of Chromolaena odoratum (Linn.) leaves. Asian Journal of Pharmaceutical \& Biological Research, 3(1), 34-35. Retrieved from http://www.wjpr.net

Delahaye, C., Rainford, L., Nicholson, A., Mitchell, S., Lindo, J., \& Ahmad, M. (2009). Antibacterial and antifungal analysis of crude extracts from the leaves of Callistemon viminalis. Journal of Medical and Biological Sciences, 3(1), 1-7.

Eze, E. A., Oruche, N. E., Onuora, V. C., \& Eze, C. N. (2013). Antibacterial screening of crude ethanolic leaf extracts of four medicinal plants. Journal of Asian Scientific Research, 3(5), 431-439. Retrieved from http://aessweb.com/journal-detail.php?id=5003

Kigigha, L. T., \& Zige, D. V. (2013). Activity of Chromolaena odorata on enteric and superficial etiologic bacterial agents. American Journal of Research Communication, 1(11), 266-276. Retrieved from http://www.usa-journals.com

Kothari, V., Gupta, A., \& Naraniwal, M. (2012). Comparative study of various methods for extraction of antioxidant and antibacterial compounds from plant seeds. Journal of Natural Remedies, 12(2), 162-173. http://dx.doi.org/10.18311/jnr/2012/271

Kusuma, I. W., Murdiyanto, Arung, E. T., Syafriza, \& Kim, Y. (2014). Antimicrobial and antioxidant properties 
of medicinal plantr used by the Bentian tribe from Indonesia. Food Science and Human Wellness, 3, 191-196. http://dx.doi.org/10.1016/j.fshw.2014.12.004

Lavanya, G., \& Brahmaprakash, G. P. (2011). Phytochemical screening and antimicrobial activity of compounds from selected medicinal and aromatic plants. International Journal of Science and Nature, 2(2), $287-291$. Retrieved from http://www.scienceandnature.org

Maji, S., Dandapat, P., Ojha, D., Maity, C., Halder, S. K., Das Mohapatra, P. K., ... Mondal, K. C. (2010). In vitro antimicrobial potentialities of different solvent extracts of ethnomedicinal plants against clinically isolated human pathogens. Journal of Phytology, 2(4), 57-64. Retrieved from http://www.journal-phytology.com

Mangicaro, S. (2012). Fomites: a vector for infection transmission. Retrieved from http://www.gnyhaservices.com/801/File.aspx

Maryam, A., Hadiza, U. S., \& Aminu, U. M. (2014). Characterization and determination of antibiotic susceptibility pattern of bacteria isolated from some fomites in a teaching hospital in northern Nigeria. African Journal of Microbiology Research, 8(8), 814-818. http://dx.doi.org/10.5897/AJMR20136512

Mondal, K. C., Bhargava, D., Shivapuri, J. N., \& Kar, S. (2012). In vitro antigonorrhoeal activity and extraction of chemical constituents from the leaves of Chromolaena odorata (Lin.) locally known as 'BANMARA'. International Journal of Chemical and Analytical Science, 3(7), 1487-1495.

Naczk, M., \& Shahidi, F. (2006). Phenolics in cereals, fruit and vegetables: occurrence, extraction and analysis. Journal of Pharmaceutical and Biomedical Analysis, 41, 1523-1542. http://dx.doi.org/10.1016/j.jpba.2006.04.002

Naidoo, K. K., Coopoosamy, R. M., \& Naidoo, G. (2011). Screening of Chromolaena odorata (L.) King and Robinson for antibacterial and antifungal properties. Journal of Medicinal Plants Research, 5(19), 4859-4862. Retrieved from http://www.academicjournals.org/JMPR/

Peñarrieta, J. M., Alvarado, J. A., Bergenstahl, B., \& Akesson, B. (2007). Spectrophotometric methods for the measurement of total phenolic compounds and total flavonoids in foods. Revista Boliviana de Quimica, 24(1), 5-9. Retrieved from http://www.researchgate.net/publication/235769282

Phan, T. T., Wang, L., See, P., Grayer, R. J., Chan, S. Y., \& Lee, S. T. (2001). Phenolic compounds of Chromolaena odorata protect cultured skin cells from oxidative damage: implication for cutaneous wound healing. Biological \& Pharmaceutical Bulletin, 24(12), 1373-1379. http://doi.org/10.1248/bpb.24.1373

Pisutthanan, N., Liawruangrath, B., Liawruangrath, S., Baramee, A., Apisariyakul, A., Korth, J., \& Bremner, J. B. (2005). Constituents of the essential oil from aerial parts of Chromolaena odorata from Thailand. Natural Product Research, 20(6), 636-640. http://doi.org/10.1248/bpb.24.1373

Queensland Department of Agriculture, Fisheries and Forestry. (2013). Siam weed Chromolaena odorata. Retrieved from http://www.daff.qld.gov.au/documents/Biosecurity_EnvironmentalPests/IPA-Siam-WeedPP49.pdf

Schwalbe, R., Steele Moore, L., \& Goodwin, A. C. (2007). Antimicrobial Susceptibility Testing Protocols. CRC Press, Boca Raton FL, USA.

Stanley, M. C., Ifeanyi, O. E., Nwakaego, C. C., \& Esther, I. O. (2014). Antimicrobial effects of Chromolaena odorata on some human pathogens. International Journal of Current Microbiology and Applied Sciences, 3(3), 1006-1012. Retrieved from http://www.ijcmas.com

Sukanya, S. L., Sudisha, J., Hariprasad, Niranjana, S. R., Prakash, H. S., \& Fathima, S. K. (2009). Antimicrobial activity of leaf extracts of Indian medicinal plants against clinical and phytopathogenic bacteria. African Journal of Biotechnology, 8(23), 6677-6682. Retrieved from http://www.academicjournals.org/AJB

Sukanya, S. L., Sudisha, J., Prakash, H. S., \& Fathima, S. K. (2011). Isolation and characterization of antimicrobial compound from Chromolaena odorata. Journal of Phytology, 3(10), 26-32. Retrieved from http://eprints.uni-mysore.ac.in/id/eprint/12645

Suksamrarn, A., Chotipong, A., Suavansri, T., Boongird, S., Timsuksai, P., Vimuttipong, S., \& Chuaynugul, A. (2004). Antimycobacterial activity and cytotoxicity of flavonoids from the flowers of Chromolaena odorata. Archives of Pharmacal Research, 27(5), 507-511. Retrieved from http://apr.psk.or.kr

Tiwari, P., Kumar, B., Kaur, M., Kaur, G., \& Kaur, H. (2011). Phytochemical screening and extraction: A review. International Pharmaceutica Sciencia, 1(1), 98-106. Retrieved from http://www.ipharmsciencia.com 
Venkata, R. B., Samuel, L., Pardha, S. M., Narashimha, R. B., Naga, V. K. A., Sudhakar, M., \& Radhakrishnan, T. M. (2012). Antibacterial, antioxidant activity and GC-MS analysis of Eupatorium odoratum. Asian Journal of Pharmaceutical and Clinical Research, 5(2), 100-106.

Vijayaraghavan, K., Ali, S. M., \& Maruthi, R. (2013). Studies on phytochemical screening and antioxidant activity of Chromolaena odorata and Annona squamosa. International Journal of Innovative Research in Science, Engineering and Technology, 2(12), 7315-7321. Retrieved from http://www.ijirset.com

Vital, P. G., \& Rivera, W. L. (2009). Antimicrobial activity and cytotoxicity of Chromolaena odorata (L. f.) King and Robinson and Uncaria perrottetii (A. Rich) Merr. extracts. Journal of Medicinal Plants Research, 3(7), 511-518. http://doi.org/10.1016/S1995-7645(11)60202-2

Yahya, M. F. Z. R., Ibrahim, M. S. A., Zawawi, W. H. A. W. M., \& Hamid, U. M. A. (2014). Biofilm killing effects of Chromolaena odorata extracts against Pseudomonas aeruginosa. Research Journal of Phytochemistry, 8(3), 64-73. http://doi.org/10.3923/rjphyto.2014.64.73

\section{Copyrights}

Copyright for this article is retained by the author(s), with first publication rights granted to the journal.

This is an open-access article distributed under the terms and conditions of the Creative Commons Attribution license (http://creativecommons.org/licenses/by/3.0/). 